\title{
A Legislative/Legal History of Prescription Drug Advertising and Promotion Regulation
}

\author{
Stephen Li and Iris Gibbs \\ Gibbs Pharma Solutions, Cambridge, MA, USA
}

Corresponding author: Stephen Li, Gibbs Pharma Solutions/CAPSTONE PSC, 434 McGrath Hwy, Ste 209, Somerville, MA 02143 USA, Tel: (781) 738-5748, email: stephen.li.a@ utoronto.ca

Received June 30, 2021; Revised, July 10, 2021, Accepted, July 14, 2021; Published, July 22, 2021

\begin{abstract}
Purpose: The communication by pharmaceutical companies of promotional messages about their products has long been controversial, but deemed to be necessary by the pharmaceutical industry so that health care professionals and in some cases patients/consumers can be made aware of the latest developments through the communication vehicles they are accustomed to seeing - in the case of health care professionals, through medical advertising, direct mail, visits by company representatives, and attendance at medical meetings, and in case of patients, through the news media and television advertising. On the other hand, critics argue that such promotion, which sometimes reduces complex medical issues to advertising slogans, is inappropriate for products intended to treat and cure diseases, and that health care professionals should learn about new products from peerreviewed medical literature. Consequently, advertising, and promotional programs are heavily regulated by the U.S. Food and Drug Administration (FDA). However, the laws themselves raise constitutional issues of infringement on free speech. Over the past few years, a number of lawsuits have been decided that help clarify the role of the FDA and the extent of its authority in regulating what companies or their employees say about their products. These court decisions are important because they help define how health care professionals and patients/consumers receive medical information. Methods: This overview is intended to identify, in non-technical language, some of the more controversial and challenging issues involved in the FDA's efforts to regulate marketing communications by drug companies and how the courts view them. Results: The recent lawsuits often involve complex and far-reaching legal issues. But when examined in toto, as this paper does, they have reflected a view by the courts that truthful and non-misleading statements by drug companies about their products can be legally communicated even when the medical information is not formally approved by the FDA and included in the FDA-approved labeling. The lawsuits thus have led to an environment in which the FDA continues to oversee with great fervor the activities of drug companies in communicating medical information but at the same time having some flexibility in keeping health care professionals and patients up to date with the latest information about medical research and new therapeutic products. Conclusion: How pharmaceutical products are marketed has been deemed by the U.S. Congress to be important enough to need to be subject to federal regulation. The issues create a tension between the need for medical information to be accurate and balanced, and the guarantees of free speech. This review provides an important perspective on how this tension is being resolved, even as dramatic advances in both medical products and technology create new challenges.
\end{abstract}

\section{INTRODUCTION}

The advertising and promotion of prescription pharmaceuticals are highly regulated by the Food and Drug Administration. The regulatory requirements are among the most stringently applied to any category of products. The FDA has dozens of pharmacists and other professionals overseeing the accuracy and integrity of advertising and promotion for prescription drugs.

The goal of the effort is to assure that medical product companies in the pharmaceutical industry promote and market their products so that they are used safely, effectively, and only when needed to treat a patient, and have the best likelihood of improving health while also managing reasonable risks. The same regulatory restrictions and policies 
apply to biological products and, with some exceptions, to medical devices.

The regulatory review of advertising and promotional materials for prescription drugs is both an art and a science. While statutes, regulations, and policies exist in writing, they need to be interpreted to a high degree, and the application of the governmental policies often is subjective since each drug has a unique scientific history, benefits, and risks. Further, no drug can ever be completely safe for all patients and each patient will respond in an individual way to treatment.

The development of advertising and promotional materials for prescription drugs bears a very high level of responsibility, since health care professionals and patients often make critical health care decisions based on a large extent on what the promotional materials say. The level of responsibility is especially high in the United States because the FDA does not restrict the use of any communication vehicle. Thus, promotion of prescription drugs is seen in virtually all communication channels - television, print publications, internet, billboards, posters, and exhibits, etc. A significant challenge that is unique to two countries - the United States and New Zealand,- is in the form of advertising that is directed at the patients themselves. These two countries are the only two countries in the world that permit Direct-to-Consumer (DTC) advertising of prescription drugs. When a product is marketed directly to patients who do not have deep medical knowledge of pharmaceuticals and diseases, there is obviously a special responsibility.

Advertisements and

promotional communications for prescription drugs and other medical products financially benefit the companies that make the products, because there is expected to be and usually is an uptake of prescriptions and an increase in sales. However, advertising and promotion also play a central role in communicating vital information and educating users, patients, healthcare professionals, payors, and many other stakeholders to better understand these medical products.

The FDA is responsible for overseeing prescription product advertising and promotion. The FDA legal authority is based on a number of laws enacted over the past century plus. It is important to understand that these laws were all passed by the U.S. Congress which, by enacting these laws, deemed control of advertising and promotion of prescription products to be worthy of federal oversight.

Over the years, the FDA has published detailed regulations and guidances that establish the guardrails for promotional activities and materials. In essence, the FDA requires that such advertising and promotion not only be truthful, but that claims made for a product be based on substantial scientific evidence (as stated in the product's FDA-approved labeling or in scientifically-valid studies), that all necessary facts about a product be communicated, that whenever a claim of benefit is made there are clear statements about the safety and risks associated with the product, and that detailed information about the product be readily available, usually through easy access to the full prescribing information.

Non-compliance with the advertising and promotion requirements of the law and the regulations is a criminal offense. But it did not start out that way more than a century ago when Congress first imposed controls over the promotion of medicines.

\section{WHERE IT STARTED}

The regulation of prescription drug promotion has evolved over time, necessitated by the everchanging social, technological, and political environment. The Food and Drugs Act (also known as the Pure Food and Drugs Act) and Meat Inspection Act of 1906 in the United States were originally enacted largely because of revelations and public outcries of the putrid conditions in the meat industry in Chicago, exploitation of workers, and adulteration and misbranding of food, but the law also encompasseddrugs because of concerns about the quality of the drug products then being marketed and the claims being made for and about them.

The Food and Drugs Act was the first statute that gave federal government enforcement power to criminally prosecute and seize goods that were considered adulterated and/or misbranded in interstate commerce. It was the first legislation to introduce the concepts of adulteration and misbranding. "Adulteration" concerns primarily the composition of a drug, while "misbranding" is defined as labels or packaging that "are false or misleading." Many manufacturers that sold "cures" for various ailments and chronic diseases were prosecuted after the 1906 statute was enacted [1].

The path to assuring that medical claims for drug products were reliable was not a direct one. United States v. Johnson, 211 U.S. 488 (1911) [2] 
tested the interpretation of the statute. In this case the U.S. Supreme Court affirmed the District Court's judgment in quashing the indictment of Dr. Johnson for packages of medicine shipped in interstate commerce that were labeled as effective in curing cancer. The Court ruled that, per Section 8 of the 1906 Food and Drugs Act, the misbranding law prohibited misleading statements about the identity of a drug including its strength, quality, and purity, but did not prohibit unapproved therapeutic claims irrespective of the intention to defraud [3]. Furthermore, the Supreme Court said that therapeutic claims would be a matter of opinion and as there was no scientific authority to ascertain therapeutic claims, a company could not be prosecuted unless there was intentional fraud [4].

In 1912, the US Congress amended the Food and Drugs Act and extended the definition of misbranding of drugs, among other changes, to include intentional fraudulent curative and therapeutic claims on or within packages of the drug. This amendment was known as the Sherley Amendment.

Just a short time later, Seven Cases of Eckman's Alternative v. United States, 239 U.S. 510 (1916) [5] tested the Sherley Amendment, where the Supreme Court upheld a judgment against fraudulent curative advertising made on circulars that were placed within the bottles of the drug. Specifically, the appellant intentionally claimed that the drug could cure pneumonia and tuberculosis when it was established that the appellant in fact had strong knowledge otherwise.

Nonetheless, the intent of fraudulent claims could not always be easily established and advertisements that were not part of the package of the drug could not be prohibited as misbranding under the Sherley Amendment. Many manufacturers took advantage of this loophole and sponsored false and misleading advertising. The next two decades saw continued pressure on Congress to pass bills to overhaul the food and drug law, as many tragedies ensued from mislabeled and falsely advertised medical and medicinal products. As safe products came on the market, it became clearer that the 1906 Food and Drugs Act was no longer deemed to be adequate.

\section{Federal Food, Drug, and Cosmetic Act of 1938}

The elixir sulfanilamide tragedy - in which more than 100 people died due to a lethal antifreeze ingredient added as a solvent to an antibacterial drug product -- was the event (but not the only one) which pushed Congress to finally enact a new law. It was signed by President Franklin Roosevelt in 1938 as the Federal Food, Drug, and Cosmetic Act (hereafter "FDCA"). The FDCA revitalized the food and drug products oversight, making regulation more relevant to the social, economic, technological, and political environment of the time. Some key elements that were established by the new law included the extension of federal regulation to cosmetics and medical devices, requirement of safety data for drugs before marketing, and harsher enforcement actions and penalties.

The proof of fraud was also no longer required to establish false promotional claims for drugs as was the case under the Sherley Amendment. The definition of misbranding was extended to mandate adequate directions for use and warnings of medical products, among other features, and labels that were deemed "false and misleading in any particular" were prohibited. The definitions of labeling and misbranding established in the FDCA in 1938 are still relevant and applied today. These two terms, "false and misleading", remain the cornerstone of regulatory advertising and promotion review standards.

Now we fast-forward to 1962 . Between 1938 and 1962, the world of medicine had changed. During World War II, penicillin was developed into an effective antibiotic, and many other drugs were developed and marketed. The Congress held hearings that identified what were characterized as marketing abuses by the industry. In 1962, Congress passed major amendments to the FDCA which established a new framework for the regulation of prescription drugs and among those amendments was a section that gave the FDA new authority to regulate prescription drug promotion.

Known as the Kefauver-Harris Amendments of 1962, the new law required manufacturers to show efficacy in addition to safety for all new drugs, as per 21 U.S.C. $\$ 355$, the official federal code of laws enacted by the US Congress. The efficacy requirement under the Kefauver-Harris Amendments is a key consideration when defining what constitutes a misbranded drug. 21 U.S.C. $\S 321$ (n) specifically states that the labeling or advertising of a product would constitute misbranding if any representation of or material fact about the drug may result in the use of the drug outside of the prescribed condition of use (i.e., the approved labeling). The requirement that drugs be shown to be effective as well as safe led to the system of clinical testing that we see to this day. 
With regard to the FDA's new authority to regulate prescription drug promotion, in the 1960s the FDA issued detailed regulations, still in effect (21 C.F.R. Part 202), that set forth its requirements for complying with the 1962 law. The regulations articulate a drug is misbranded if the labeling or advertisement does not represent the drug accurately or in a balanced way, especially when the labeling or advertising suggests uses for conditions which have not been approved by the FDA.

In the 1990's, as companies used advertising and promotion programs more commonly for their products, including the use of television advertising, the FDA dramatically increased its oversight and enforcement of the prescription drug promotional regulations. The number of FDA staff involved in enforcement increased by orders of magnitude, as did the number of enforcement actions. In 1991, the Division of Drug Marketing, Advertising and Communication (DDMAC) was established within the Center for Drug Evaluation and Research to bring into focus a new oversight and enforcement approach. Since then, the oversight has continued and DDMAC's successor, now known as the Office of Prescription Drug Promotion (OPDP), continues to take enforcement action in the form of letters sent to violators. These untitled letters or titled warning letters are preliminary vehicles by which OPDP communicates its concerns or warnings on the promotional practices, i.e., materials a company makes public in promoting its drug products.

Toward the late 1990's a new element was added when the Office of Inspector General (OIG) in the Department of Health and Human Services applied two of its own statutes, the False Claims Act and the Anti-Kickback Statute, to bring legal actions against drug companies for off-label promotion or other alleged infractions. The settlements in these cases sometimes were several billion dollars, based on how much the government alleged that the companies profited from off-label promotion. Virtually all major companies have paid fines, many of them quite substantial, for violations in cases brought by the OIG. The basic violation cited is offlabel promotion, almost always also identified by the FDA, so the FDA oversight of promotional activities has had financial implications for the entire drug industry. It is important for regulatory advertising and promotional professionals to understand that these various federal governmental agencies work in concert to bring about these legal actions against pharmaceutical companies.
In May 2003, the OIG issued a list of elements for what it regarded as an effective compliance program for drug companies, and the OIG document has led to the creation of compliance programs in virtually all drug companies. In addition, the major industry trade association has issued codes that define an appropriate relationship between drug companies and health care professionals, and that define standards for DTC advertising, and these codes have been followed by most drug companies. To be clear, the companies that wish to avoid enforcement actions from the OPDP follow these standards.

\section{Current Trends}

According to a study published in the Journal of the American Medical Association (JAMA), total spending on the marketing of drugs by pharmaceutical companies has increased quite significantly over the years [6]. In particular, DTC advertising prescription drugs increased from $\$ 1.3$ billion in 1997 to $\$ 6$ billion in 2016. The authors noted a shift toward advertising high-cost biologics and cancer immunotherapies, and marketing to health professionals (such as detail aids, samples, disease education, and payments as speakers) accounted for most of the promotional spending, which increased from $\$ 15.6$ billion to $\$ 20.3$ billion in the same period [7]. Not surprisingly, sales of prescription drugs also increased during the same period.

Previously published studies concluded that DTC advertising of prescription drugs was associated with increased patient requests and prescription of the advertised products. However, there was no evidence that suggested an improvement in medical treatment, adherence, or better information due to the increase in DTC advertising of these drugs $[8,9,10,11]$.

Over the years since the 1962 Amendments, the FDA has taken enforcement action against violations. Enforcement actions by the FDA on advertising and promotions considered "misbranding" were quite numerous in the late 1990 's to the early 2000's to ensure the industry was operating in line with the regulations. Most enforcement actions have cited risk minimization, unproven efficacy claims, and unsubstantiated superiority claims $[12,13]$.

The challenge faced by the FDA today is to provide an ongoing framework for the communication of proper information on medical products, while curtailing untruthful and misleading 
claims. This is the objective of these authors, to help provide a framework of the ongoing advancements and progress with respect to drug promotion. The authors are responsible for reviewing drug ads and promotion material which are delivered in print, by oral presentation, electronic, digital, recorded, and social media mediums to physicians, pharmacists, pharmacy purchasing organizations, patients, and other consumers. This article advances the nonlawyer and regulatory reviewer's knowledge in the field by summarizing the legal decisions on the regulation of US pharmaceutical drug advertising and promotion.

\section{MAJOR AND RECENT COURT CASES}

FDA's regulations require that promotional materials for prescription drugs promote only approved or substantiated claims and balance risk information with benefit information. The devil is in the details, of course, and how this balance is achieved is complex. FDA has issued many guidances to explain its views on various promotional issues, but to assure compliance, companies need multiple experts to review every word in a promotional piece, and debates even among the experts reflects how subjective the application of the regulations has become.

Over the years there have arisen a number of important court cases that provide focus on some of the more controversial issues and provide some insight into how the courts view FDA regulation, especially given the inevitable First Amendment free speech concern. Here are some of the major court cases, with an emphasis on the most recent ones, that are relevant and that help elucidate some of the challenges faced by drug companies as they seek to orchestrate the conveyance of accurate and timely information to their various audiences in a manner that is consistent with the laws and with the FDA's application of them.

\section{Kordel}

In an opinion written by Supreme Court Justice Douglas in U.S. v. Kordel, 335 U.S. 345 (1948) that "the separate shipment of pamphlets after the shipment of the drugs did not save the drugs from being misbranded, by way of false labeling [as the pamphlets contained false efficacy claims] within the meaning of 21 U.S.C. $\S 502$ (a) of the FDCA, [where] 21 C.F.R. Part 201 (m) defines "labeling" as including all printed matter accompanying an article."[14]
This has been the undisputed regulatory scope since 1948. A promotional piece need not actually physically accompany a drug for it to be considered promotional and subject to FDA oversight. Obviously in today's environment, the vast majority of promotional materials do not physically accompany the actual drug.

\section{Washington Legal Foundation}

Washington Legal Found. v. Friedman, 13 F. Supp. 2d 51 (1998) [15] was a case where the Washington Legal Foundation (WLF) successfully sought to prevent the FDA from taking enforcement actions to prevent the distribution by companies of off-label peer-reviewed journal articles and their sponsorship of Continuing Medical Education (CME) programs. The FDA argued in court that its guidance documents were meant to restrict conduct rather than restrict speech, but the court opined that the off-label prescription of drugs by physicians would be a form of conduct, and the promotion of off-label use by manufacturers would clearly be a form of speech [16].

In fact, the court stated that in another case, Posadas de Puerto Rico Assoc. v. Tourism Co. of Puerto Rico., 478 U.S. 328 (1986) [17] that "the First Amendment makes clear that the Constitution presumes that attempts to regulate speech are more dangerous than attempts to regulate conduct. That presumption accords with the essential role that the free flow of information plays in a democratic society. As a result, the First Amendment directs that the government may not suppress speech as easily as it may suppress conduct."'[18]

The FDA asserted that the speech that it sought to regulate would not be protected under the First Amendment because of the federal government's extensive power to regulate the pharmaceutical industry in other areas. The court stated that under a case known as Central Hudson Gas and Electric Corp. v. Public Service Comm'n of New York, 447 U.S. 557 (1980) [19], "the Supreme Court has consistently applied a speech analysis - whether under the pure speech or commercial speech framework - to cases involving statutes and/or regulations in areas subject to extensive state or federal regulation"[20] In fact, the court noted that areas subject to extensive regulation are to be scrutinized as commercial speech, and that such issue was resolved in Liquormart, Inc. v. Rhode Island, 517 U.S. 484 [21]. 
The District Court in the WLF case further noted that courts assessed the constitutionality of various FDA labeling, advertising, and promotion regulations and/or disclosure requirements proceeded directly to a commercial speech analysis [22].

Nevertheless, the WLF case was unique in that the materials of subject in the case were peerreviewed scientific journals and CME programs. This raised the question of whether dissemination of such scientific materials would be protected fully by the First Amendment as speech or that, because such materials and events were provided and sponsored by manufacturers with the intent to influence prescribing behaviors of physicians, it would have a lesser degree of protection under the First Amendment as commercial speech. The FDA successfully provided substantial evidence of the correlation in the WLF case that making physicians aware of research concerning the manufacturer's drugs would have a positive effect on the number of prescriptions written and would equal to a positive effect on sales [23]. For these reasons among others, the WLF court concluded that manufacturer sponsorship of CME seminars at which the sponsor's products would be discussed and the distribution of materials that focus on the manufacturer's product would be classified as commercial speech [24].

Consistent with other courts where the Central Hudson test was applied in the context of off-label commercial speech, the court found "the restrictions in the guidance documents are more extensive than necessary to serve the asserted government interest [i.e. off-label uses of drugs are subject to the FDA's evaluation process [25]] and that they unduly burden important speech. Therefore, the guidance documents fail the fourth prong of the Central Hudson test, rendering them incompatible with the First Amendment."[26]

The WLF case may seem to involve just legal debate over definitions, but in fact it was viewed by many in the industry as opening doors for the proactive dissemination of peer-reviewed articles and the sponsorship by companies of CME programs.

\section{Caronia}

In the Caronia case, United States v. Caronia, 703 F.3d 149 (2012) [27], the appellant was Alfred Caronia, a pharmaceutical sales representative who promoted the drug Xyrem for off-label use. Caronia argued that his conviction for promoting an FDAapproved drug for off-label use violated his right of free speech under the First Amendment. The Circuit
Court agreed and vacated the judgment of conviction and remanded the case to the District Court [28].

The Circuit Court noted that courts and even the FDA recognized the potential public value of unapproved or off-label drug use [29]. Chief Justice Rehnquist of the Supreme Court noted that in Buckman Co. v. Plaintiffs' Legal Comm., 531 U.S. 341 (2001), "off-label use is an accepted and necessary corollary of the FDA's mission to regulate in this area without directly interfering with the practice of medicine."[30] Circuit Judge Chin further stated in the Caronia case that "the FDCA itself does not expressly prohibit or criminalize offlabel promotion. The FDCA defines misbranding in consideration of whether a drug's labeling is adequate for its intended use, and permits the government to prove intended use by reference to promotional statements made by drug manufacturers or their representatives."[31] In other words, a conviction on misbranding would be based on the intended use prescribed by the manufacturer or its representatives. Promotional statements made by the manufacturer, or its representatives could be used as evidence by the government to support such allegations, but promotional statements alone would not be considered substantial material of a misbranding conviction."

There was no evidence produced in the case that alleged Caronia conspired to making false or misleading labeling claim of intended use of the drug. Thus, the Caronia case was never about intent. Caronia's promotion and marketing efforts were deemed to be commercial speech. For this reason (among others), the Circuit Court held that "the government cannot prosecute pharmaceutical manufacturers and their representatives under the FDCA for speech promoting the lawful, off-label use of an FDA-approved drug and, as such, speech would be protected by the First Amendment." [32]

This case also has ripple effects within the industry as it appeared the courts had brought First Amendment protections directly into the debate and stated that statements by drug company employees that were off-label but otherwise truthful could be afforded protection.

\section{Amarin}

Amarin Pharma, Inc. v. United States FDA, 119 F. Supp. 3d 196 (2015), further tested the FDA's authority in regulating off-label promotion [33]. In this case, the company completed a clinical study through the FDA's Special Protocol Assessment, where the company worked closely with the FDA to 
agree on the design of the study used as the basis for seeking a new indication for its product, which lowered triglyceride levels.

Although the clinical data from the study were statistically significant (and the FDA acknowledged the positive results), the FDA issued a Complete Response Letter at the end of its review of Amarin's application. The FDA's rationale for not approving the new use was that similar studies of the same drug class completed by other companies did not substantiate a correlation between high triglyceride levels and reduction in cardiovascular risks.

The Complete Response Letter also stated that "[the] product may be considered to be misbranded under the [FDCA] if it is marketed with this change before approval of this supplemental application.'[34] Amarin sought preliminary relief to ensure its ability to make truthful and nonmisleading promotional speech based on the study, free from the threat of misbranding action by the FDA [35]. The Court granted Amarin's application for preliminary relief. [36]

District Judge Engelmayer wrote in his opinion of the Amarin case, which reinforced the holding of the Second Circuit of the Caronia case, that the government could not prosecute pharmaceutical manufacturers and their representatives under the FDCA for speech promoting the lawful, off-label use of an FDA-approved drug [37]. The FDA argued that protection of truthful promotion of off-label drug use would undermine the FDA drug approval process. The Court dismissed the FDA and noted that the drug approval framework predated the modern First Amendment law. The Supreme Court held in Cent. Hudson Gas \& Elec. Corp. v. Public Serv. Comm'n, 447 U.S. 557 (1980) [38] that commercial speech, and specifically, pharmaceutical marketing as in Sorrell v. IMS Health Inc., 564 U.S. 552 (2011) [39] would be protected under First Amendment law. Furthermore, the current FDCA misbranding provisions "must be considered in light of contemporary First Amendment law, under which truthful and non-misleading commercial speech is constitutionally protected, subject to the Central Hudson framework." The Circuit Court in the Caronia case identified an alternative and less speech-restrictive means for the FDA to achieve its objectives in the regulation of prescription drug marketing [40].

The FDA argued in the Amarin case that the court should limit First Amendment protection to only a certain type of truthful and non-misleading off-label statements made by a manufacturer. For example, the FDA stated in court that statements made in response to a doctor's query (as opposed to those proactively made to a doctor); and statements made by a scientist or physician (as opposed to a sales or marketing employee) would more accurately point to the lack of intent to promote intended use of the drug that has not been approved by the FDA. The court noted that intent was not an element in the Caronia case, and that the holding of the District Court in Caronia would apply across-the-board to all truthful and non-misleading promotional speech [41].

Last, the FDA argued that truthful and misleading statements could be used as evidence to establish intent. However, the Amarin court noted that, in Caronia, the case was about the statute's limitation on truthful and non-misleading promotional speech while, in the Amarin case, the company sought preliminary relief aimed at misbranding action against truthful and nonmisleading speech. Neither cases were about intent [42].

By and large, Caronia and Amarin could be construed to mean that promotional off-label speech of truthful and non-misleading statements could not be criminally prosecuted, subject to the Central Hudson analysis. Nevertheless, it should be noted that "intent" was never challenged in court in these two cases.

\section{Pacira}

The Pacira case (Pacira Pharmaceuticals, Inc. v. FDA, 15-cv-07055 [43]) involved the promotion of a drug for a broader range of surgical procedures than were included in its pivotal studies, even though the promotional materials actually disclosed that the drug was indeed tested in only the two surgical procedures. The FDA issued a Warning Letter to Pacira in September 2014 that objected to such materials as an unlawful broadening of the approved indication.

In Pacira's lawsuit against the FDA, the company stated that truthful and non-misleading promotion of off-label uses for its product would be protected by the First Amendment. The lawsuit claimed that the Agency reversed its position during labeling negotiations to limit the indication. The implication was that the Agency had at some point agreed that the broader indication would be valid. Pacira was also able to substantiate that the procedures and endpoints studied in the pivotal trials were specifically chosen to permit broader extrapolation to similar procedures [44]. 
Pacira reached a settlement with the FDA in late 2015 when the Agency rescinded its Warning Letter. Although the FDA gave no reason for withdrawing the letter, it could be that the Agency thought its chance in court would have been marginalized given the Caronia and Amarin cases.

\section{DISSEMINATION OF PEERED-REVIEWED JOURNALS AND CME PROGRAMS}

By and large, off-label promotions, peered-reviewed scientific journals, and CME programs are all considered commercial speech, which would be protected by the First Amendment as seen in many cases including Caronia, Amarin, and WLF. This means the FDA cannot prohibit off-label promotions as it would be deemed unconstitutional. In determining whether specific government restrictions can be applied to such commercial speech, the courts generally apply the Central Hudson test to determine whether a particular commercial speech would be protected by the First Amendment, provided the activities in question are lawful and that the information in the advertising and promotion materials are not misleading.

\section{CONCLUSION}

This paper seeks to provide a summary of the early legislative and recent legal history of the FDA's oversight over the advertising and promotion of prescription products, mainly drugs (although the same principles apply to biologics and devices). It is clear that this is an area still evolving, since the most recent court cases were brought many decades after the enactment of the 1962 Amendments. This study also illuminates the fact that life science manufacturers have some latitude, based on recent court decisions, to provide truthful information about their drugs' off label use under the protection of commercial speech.

What the future has in store remains to be seen. How drugs and other medical products are advertised and promoted has changed dramatically since 1962 and continues to change virtually every day. With these changes, the federal government needs to decide how best to enforce the law and what changes may be needed to accommodate advances in technology, medical practice, and patient involvement in medical care.
CONFLICT OF INTEREST. None to declare, however, both authors provide services to pharmaceutical companies. The content of the paper is the personal opinion of the authors.

\section{REFERENCES}

1. https://www.fdareview.org/issues/history-offederal-regulation-1902-present/\#p05

2. https://www.fdareview.org/issues/history-offederal-regulation-1902-present/\#p05

3. A practical guide to FDA's food and drug law and regulation. Washington, D.C.: Published by The Food and Drug Law Institute, FDLI. (page 24-5)

4. https://www.fdareview.org/issues/history-offederal-regulation-1902-present/\#p05

5. Seven Cases of Eckman's Alterative v. United States, 239 U.S. 510 (1916)

6. Kravitz, RL, Epstein, RM, Feldman, MD, et al (2005). Influence of patients' requests for direct-to-consumer advertised antidepressants: a randomized controlled trial. JAMA, 293(16), 1995-2002.

7. Schwartz, L. M., \& Woloshin, S. (2019). Medical Marketing in the United States, 19972016. JAMA,321(1), 80.

8. Gilbody, S. (2005). Benefits and harms of direct to consumer advertising: A systematic review. Quality and Safety in Health Care, 14(4), 246-250.

9. Kravitz, RL, Epstein, RM, Feldman, MD, et al (2005). Influence of patients' requests for direct-to-consumer advertised antidepressants: a randomized controlled trial. JAMA, 293(16), 1995-2002.

10. Frosch, D. L., Grande, D., Tarn, D. M., et al (2010). A Decade of Controversy: Balancing Policy With Evidence in the Regulation of Prescription Drug Advertising. American Journal of Public Health, 100(1), 24-32.

11. Mintzes, B. (2012). Advertising of Prescription-Only Medicines to the Public: Does Evidence of Benefit Counterbalance Harm? Annual Review of Public Health, 33(1), 259-277.

12. Andrew Dunn, Biopharma Dive, FDA Data

13. $\mathrm{Hu}, \mathrm{K}$., Hermes-DeSantis, E., Toscani, M., et al (2019). Trends in FDA OPDP and APLB Enforcement Letters Before and After First Amendment Cases and FDA Guidance 
Publications. Rutgers Institute for Pharmaceutical Industry Fellowships.

14. U.S. v. Kordel, 335 U.S. 345 (1948)

15. Washington Legal Found. v. Friedman, 13 F. Supp. 2d 51 (1998)

16. Id. at 59

17. Posadas de Puerto Rico Assoc. v. Tourism Co. of Puerto Rico., 478 U.S. 328 (1986)

18. Washington Legal Found. v. Friedman, 13 F. Supp. 2d 51, 61 (1998), supra note

19. Central Hudson Gas and Electric Corp. v. Public Service Comm'n of New York, 447 U.S. 557 (1980)

20. Washington Legal Found. v. Friedman, 13 F. Supp. 2d 51, 60 (1998)

21. Liquormart, Inc. v. Rhode Island, 517 U.S. 484

22. Washington Legal Found. v. Friedman, 13 F. Supp. 2d 51, 61 (1998)

23. Id. at $62-3$

24. Id. at 64

25. Id. at 63

26. Id. at 74

27. United States v. Caronia, 703 F.3d 149 (2012)

28. Id. at 152

29. Id. at 153

30. Buckman Co. v. Plaintiffs' Legal Comm., 531 U.S. 341, 350 (2001)

31. United States v. Caronia, 703 F.3d 149, 161 (2012)

32. Id. at 169

33. Amarin Pharma, Inc. v. United States FDA, 119 F. Supp. 3d 196 (2015)

34. Id. at $210-22$

35. Id. at 198

36. Id. at 237

37. Id. at 226

38. Cent. Hudson Gas \& Elec. Corp. v. Public Serv. Comm'n, 447 U.S. 557 (1980)

39. Sorrell v. IMS Health Inc., 564 U.S. 552 (2011) supra note

40. Amarin Pharma, Inc. v. United States FDA, 119 F. Supp. 3d 196, 226-7 (2015)

41. Id. at 227

42. Id. at $227-8$

43. Pacira Pharmaceuticals, Inc. v. FDA, 15-cv07055

44. https://www.hlregulation.com/2015/12/17/fda -settles-paciras-first-amendment-lawsuit/ (last accessed on June 16, 2019) 